\title{
IDEA PAŃSTWA ŻYDOWSKIEGO ALFREDA NOSSIGA NA TLE KSZTAŁTOWANIA SIĘ DOKTRYNY SYJONIZMU POLITYCZNEGO
}

\author{
ALFRED NOSSIG'S IDEA OF THE JEWISH STATE WITHIN \\ THE CONTEXT OF THE DEVELOPMENT OF THE DOCTRINE \\ OF POLITICAL ZIONISM
}

\author{
Michał Śliwa*
}

\begin{abstract}
ABSTRAKT
Znaczący udział w tworzeniu międzynarodowego ruchu syjonistycznego i jego doktryny politycznej miały polskie środowiska żydowskie $\mathrm{z}$ terenu Galicji i Królestwa Polskiego. Reprezentatywną dla nich postacią był Alfred Nossig (1864-1943), literat, artysta, myśliciel, polityk, wywodzący się z lwowskiej inteligencji asymilatorskiej. W obliczu nasilających się procesów narodowotwórczych, rozbudzenia aspiracji narodowych Żydów w Europie Środkowo-Wschodniej i postępów ruchu syjonistycznego ogłosił on w 1887 roku rozprawę pt. Próba rozwiązania kwestii żydowskiej, będącą przedrukiem cyklu artykułów z poprzedniego roku, zamieszczonych w lwowskim „Przeglądzie Społecznym”. Przedstawił w niej projekt odbudowy państwa żydowskiego w Palestynie przez osadników z Europy Środkowo-Wschodniej, stanowiący założenia doktrynalne tworzącego się nowego ruchu żydowskiego. Jednakże w wyniku różnych uwarunkowań podstawą doktrynalną międzyna-
\end{abstract}


rodowego ruchu syjonistycznego nie stało się jego opracowanie, lecz dzieło Teodora Herzla Państwo żydowskie.

Słowa kluczowe: doktryna polityczna, ruch syjonistyczny, idee syjonistyczne, państwo żydowskie ish movement. However, as a result of a range of circumstances, his ideas did not become the doctrinal basis of the international Zionist movement, but instead published a decade later Theodor Herzl's oeuvre, Państwo żydowskie [The Jewish State], became one.

Keywords: political doctrine, Zionist movement, Zionist ideas, Jewish state

\section{WPROWADZENIE}

$\mathrm{Na}$ przełomie dwóch poprzednich stuleci w wyniku splotu różnorodnych czynników i uwarunkowań wzmagały się na niespotykaną dotąd skalę procesy narodowotwórcze w Europie Środkowo-Wschodniej, doprowadzając do powstania po wielkiej wojnie na gruzach monarchii rosyjskiej i austro-węgierskiej nowych państw narodowych. Nie ominęły one również ludności żydowskiej, zamieszkałej nie tylko na tym obszarze starego kontynentu, lecz także w innych krajach europejskich i w Ameryce Północnej. W ostatnim bowiem ćwierćwieczu XIX wieku nasilił się proces kształtowania świadomości narodowej Żydów i rozwój politycznego ruchu syjonistycznego. Formował się on w reakcji na nowe wówczas wyzwania i problemy, przede wszystkim wzmagające się nastroje i akcje antysemickie, pojawienie się aspiracji narodowych i obywatelskich ludności żydowskiej, a w konsekwencji zaognienie się na niespotykaną dotąd skalę kwestii żydowskiej. Poszukiwano różnych sposobów jej rozwiązania już jako zjawiska o charakterze narodowym, społecznym i politycznym, a nie tylko religijnym. Sprzyjało mu budzenie się ruchów niepodległościowych wśród wielu innych narodów europejskich oraz ich ruchów i ideologii nacjonalistycznych. Wśród samej ludności żydowskiej również narastał prąd nacjonalistyczny wskutek niezwykłego ożywienia procesów narodowotwórczych, pod wpływem gwałtownie zachodzących przemian industrializacyjnych, urbanizacyjnych i modernizacyjnych ówczesnych społeczeństw. Jeszcze przed narodzinami syjonizmu politycznego dochodziło do osiedlania się Żydów w Palestynie w celu wytworzenia nowej społeczności żydowskiej o charakterze polityczno-terytorialnym. W tej sytuacji syjonizm stawał się jedną z wielu odmian powszechnego wówczas ruchu narodowego, wywierającego decydujący wpływ na dzieje najnowsze (Hertzberg, 1986; Shimoni, 1995; Vital, 1975). 


\section{POCZĄTKI RUCHU SYJONISTYCZNEGO NA ZIEMIACH POLSKICH I PERCEPCJI IDEI SYJONIZMU}

Jednocześnie załamywał się, słaby zresztą dotąd, ruch asymilatorski. Zmiany te szczególnie zauważalne były na ziemiach polskich, przede wszystkim w Królestwie Polskim i w Galicji. Politycznym przejawem odrodzenia narodowego Żydów stawały się powstające na początku przedostatniej dekady grupy syjonistyczne Chibbat Cijon (Miłośnicy Syjonu) w wielu miastach zaboru rosyjskiego, między innymi w Warszawie, Łodzi, Piotrkowie Trybunalskim, Kaliszu, Białymstoku i Wilnie. Były one częścią rozwijającego się wówczas intensywnie w całym imperium rosyjskim szerszego żydowskiego ruchu odrodzeniowego i wyzwoleńczego w obliczu nasilających się prześladowań władz carskich, którego organizatorzy zwołali do Katowic na początku listopada 1884 roku konferencję syjonistyczną z zadaniem uporządkowania spraw organizacyjnych i opracowania założeń ideowych (Zineman, 1935; Wróbel, 1991; Sroka, Bruti, 2017). Inicjatorem jego był lekarz i filozof pochodzący z terenu dzisiejszej Ukrainy i rozwijający działalność głównie w imperium carskim - Leon Pinsker. Był on jednym z bardziej popularnych ideologów syjonizmu w Polsce, którego koncepcje upowszechniano i komentowano. On też przygotował podstawy ideowe nowego ruchu - Miłośników Syjonu i stanął na jego czele. Dwa lata wcześniej ogłosił w Berlinie głośną rozprawę: Autoemanzipation!, Mahnnruf an Seine Stammesgenossen von einem russischen Juden, której polskie wydanie ukazało się dopiero w 1900 roku, dwukrotnie jednak później jeszcze wznawiane w latach trzydziestych XX wieku. Zwracał się w niej do zachodnioeuropejskiej społeczności żydowskiej, by ta wsparła i udzieliła pomocy swym rodakom osiadłym w krajach środkowo-wschodniej części kontynentu, poddanych niesłychanemu ostracyzmowi społeczno-politycznemu, ekonomicznemu i psychologicznemu. Są oni bowiem - twierdził - najbardziej spauperyzowaną warstwą społeczną w tych krajach, prześladowaną wskutek niebywałej judeofobii, osiadłą w gettach, pozbawioną praw i skazaną na wyniszczenie. Stosunek do nich sąsiadów przybrał wręcz chorobliwy charakter, gdyż judeofobia skojarzona z różnymi przesądami, zabobonami i instynktami nienawiści stała się psychozą, a „jako psychoza - dowodził autor - jest ona nieustępliwa, a jako od dwóch tysięcy laty odziedziczona choroba - nieuleczalną. Strach przed upiorami jako ojciec judeofobii jest przyczyną, wywołującą tę abstrakcyjną, rzekłbym, platoniczną nienawiść, przez którą czyni się odpowiedzialnym cały naród żydowski za rzeczywiste lub rzekome występki poszczególnych jego członków, tylekroć ciska 
mu się w twarz oszczerstwa" (Pinsker, 1900, s.14). Nie mogą być oni w stosunku do swych sąsiadów równorzędnym czynnikiem narodowym i społecznym, ponieważ nie dysponują tym, co dzisiaj charakteryzuje nowoczesne narody: własne terytorium $z$ władzą polityczną i wspólny, rodzimy język. Nie mają więc Żydzi Europy Środkowo-Wschodniej poczucia wspólnoty terytorialnej i politycznej, czyli nowoczesnej tożsamości narodowej oraz posiadania własnej ojczyzny i państwa. Szczególna ich sytuacja wynika z faktu, iż „Żyd nigdzie u siebie w domu nie jest, nigdzie nie jest uważany za domownika - jest wszędzie obcym. Że on sam i jego ojcowie w tym kraju się urodzili, to w niczym stanu rzeczy nie zmienia. W większości wypadków traktuje się go jako pasierba, w najlepszym wypadku jako dziecko adoptowane, którego prawa można kwestionować, lecz nigdy nie jest uważany za prawowitego syna ojczyzny. Dumny ze swojej germańskości Niemiec, Słowianin, Celt nie przyznaje, jakoby mu semicki Żyd był równy. A jeśli nawet jako człowiek postępowy gotów będzie przyznać mu wszystkie prawa obywatelskie, to jednak nigdy nie dojdzie do tego, aby w tym swoim współobywatelu Żyda zapomnieć. Legalna emancypacja Żydów jest szczytowym punktem postępu naszego stulecia. Ale legalna emancypacja nie jest jeszcze towarzyską emancypacją, a dekretowanie tej pierwszej nie znosi jeszcze ekskluzywności społecznego stanowiska Żydów” (Pinsker, 1900, s. 18). Ponadto decyduje tu również czynnik religijny. Nie można bowiem zmienić ich położenia $\mathrm{w}$ krajach osiedlenia poprzez równouprawnienie i uobywatelnienie, ponieważ nie daje się to pogodzić z judaizmem - religijnym charakterem tożsamości żydowskiej. Wszak emancypacja prowadzi do wyrzeczenia się żydowskości i wykluczenia ze wspólnoty żydowskiej. Dlatego najwłaściwszym sposobem jest samowyzwolenie się (autoemancypacja) wzorem społeczeństw zachodnioeuropejskich w duchu wartości oświeceniowych, czyli odzyskanie godności ludzkiej, człowieczeństwa, wolności jednostki itp. I w konsekwencji odnowy tożsamości narodowej jako nowoczesnej wspólnoty ludzi wolnych, opartej na przesłankach politycznych, a nie religijnych, gdyż judaistyczne wyobrażenie narodu i świadomości narodowej rozmija się wyraźnie ze współczesnymi wymogami postępu i rozwoju narodu. Aczkolwiek - podkreślał autor - nie można definitywnie odrzucić historyczno-religijnych uwarunkowań nowego ruchu samowyzwoleńczego, włącznie z mesjańską ideą powrotu Żydów do historycznego Syjonu, lecz nie one mają tworzyć nadal jego podstawy ideowe. Upatrywanie bowiem rozwiązania kwestii żydowskiej w spełnieniu się wizji mesjanistycznych i bierne jej wyczekiwanie może w obecnej sytuacji ludności żydowskiej doprowadzić jedynie do upadku narodu żydowskiego. Odnowa 
przeto świadomości narodowej na gruncie politycznym, przejawiająca się w dążeniu do odbudowy państwa żydowskiego, nie wykluczone, że na terenie Palestyny, wzmocni procesy narodowotwórcze i modernizacyjne, w wyniku których Żydzi przestaną być społecznością „,wiecznych tułaczy”, kosmopolitów, przekształcając się w nowoczesny naród na konkretnym terytorium, któremu państwo zapewni zbiorowe i indywidualne bezpieczeństwo oraz odpowiednie warunki nowoczesnego i postępowego rozwoju. W ten sposób Żydzi staną się równoprawnym narodem wśród innych narodów, zyskując ich przychylność i uznanie.

Realizację owej wizji rozwiązania kwestii żydowskiej miał zapoczątkować zawiązany na wspomnianej katowickiej konferencji syjonistycznej nowy ruch polityczny - Miłośnicy Syjonu, popularyzujący akcję osadniczą na terenie Palestyny i przygotowanie Żydów osadników do pracy w rolnictwie, mającym stanowić podstawę gospodarki przyszłego państwa.

Również w Galicji zanikał ruch asymilatorski, wypierany przez budzący się ruch narodowy. Np. we Lwowie traciło na znaczeniu polonizatorskie Stowarzyszenie Przymierze Braci - Agudas Achim, ostro zwalczane przez budzący się ruch narodowy. W 1882 roku odbył się tam pierwszy wieczorek syjonistyczny. W pięć lat później Herman Diamand, przyszły czołowy polityk socjaldemokracji polskiej w Galicji, założył Stowarzyszenie „Syjon”, które ogłosiło broszurę Jakim powinien być program młodzieży żydowskiej (Lwów 1887), popularyzującą hasło osiedlania się Żydów w Palestynie. Stowarzyszenie proklamowało jednocześnie program uobywatelnienia Żydów, przebudowy stosunków żydowskich i unowocześnienia życia żydowskiego według uniwersalnych wzorów zachodnioeuropejskich, zachowując jednocześnie tradycje judaistyczne. Po kilku latach intensywnej agitacji narodowej zamarł ruch asymilatorski, i w 1892 roku w miejsce wydawanego przez Stowarzyszenie Przymierze Braci czasopisma „Ojczyzna” (1881-1892) założono dwutygodnik „Przyszłość” (1892-1899), będący pierwszym pismem syjonistycznym na ziemiach polskich. Na jego łamach uzasadniano główne dążenie nowej idei - syjonizmu: emigracji Żydów do Palestyny. Swych zwolenników mobilizowano pod hasłem: „wszystkie warstwy żydowskie budzącego się ruchu syjonistycznego i Żydzi wszystkich krajów solidaryzujcie się! Precz z wygodną maskaradą asymilacyjną! Precz ze służalczym muzykantem Jankielem i jego wielbicielami” (Feldman, 1893, s. 56; zob. też. Golczewski, 1981). Jednakże rodzący się nowy ruch żydowski nie wzbudzał poważniejszego zainteresowania ze strony polskiej opinii publicznej, której światlejszą część absorbowały głównie sprawy rodzime, polskie (Ringel, 1910). 
Natomiast młoda inteligencja żydowska $\mathrm{z}$ uwagą śledziła przemiany zachodzące wśród warstw własnego narodu w poszczególnych krajach europejskich i chłonęła napływające do kraju nowinki ideowe i propozycje polepszenia doli swych rodaków. Nie zadawalały już ją koncepcje i projekty prekursora syjonizmu politycznego Mojżesza Hessa, niemieckiego pisarza i filozofa, we wczesnym okresie ideologa socjalizmu i przyjaciela Karola Marksa i Fryderyka Engelsa. Opublikował on bowiem w 1862 roku dzieło: Rzym i Jerozolima. Ostatnia kwestia narodowa, w którym zakwestionował sens akcji asymilacyjnej i emancypacyjnej Żydów w krajach osiedlenia, propagując ideę powrotu do Ziemi Obiecanej. Tłumaczył bowiem, iż „pomimo oświecenia i emancypacji będący na wygnaniu Żyd, który wypiera się swej narodowości, nigdy nie zdobędzie szacunku narodów, wśród których mieszka. On może stać się naturalizowanym obywatelem, lecz nigdy nie będzie zdolny przekonać gojów do tego, że całkowicie oddzielił się od własnej narodowości” (Hess,1899, s. 22, cyt. za: Surzyn, 2014, 79-80). O żydowskości przesądza bowiem religia judaistyczna, określająca status narodowościowy i kulturowy wyznawcy, który choćby dokonał nowego wyboru światopoglądowego, to i tak pozostanie Żydem. Szczególny ów charakter religii mojżeszowej wynika z zawartego przymierza Boga z Żydami i uznania ich za naród wybrany, zdolny do przewodzenia całej ludzkości. Dlatego, zdaniem niemieckiego myśliciela, należy odbudować u Żydów poczucie dumy narodowej, wynikającej z samej istoty judaizmu i przekonać ich do podjęcia dzieła doskonalenia ludzkości poprzez odrodzenie idei człowieczeństwa i humanizmu. Dokona się to może w nadchodzącej nowej epoce: erze wyzwolenia człowieka i ludzkości, w wyniku którego ludzkość osiągnie nowy poziom rozwoju moralnego i społecznego, a Żydzi odbudują swoje państwo. Może to wszystko dokonać się na drodze wielkiej, powszechnej przemiany socjalistycznej, zdeterminowanej wyznaniem wiary judaistycznej, warunkiem której to przemiany jest rozbudzenie poczucia wspólnoty narodowej i dumy z żydowskości. Wstępnym przeto krokiem powrotu do Ziemi Obiecanej i odbudowy państwa izraelskiego - wnioskował M. Hess - jest kolonizacja Palestyny poprzez wykup ziemi, jej odpowiednie zagospodarowanie i przygotowanie przyszłych osadników do pracy na roli. W tym celu należy pozyskać finansjerę żydowską i poparcie niektórych państw, zwłaszcza Turcji i Francji, rozwinąć na szeroką skalę akcję edukacyjną głównie wśród młodzieży żydowskiej do osiedlania się w Palestynie, zapewniając jednocześnie osadnikom bezpieczeństwo przez odpowiednio zorganizowane własne siły militarne. Postrzegając w syjonizmie wiele cech wspólnych z socjalizmem, tworzył bowiem na ich podstawie nową synkretyczną koncepcję pełnego i ostatecznego 
wyzwolenia człowieka, ludzkości i Żydów, splatając również idee syjonizmu mesjanistycznego $\mathrm{z}$ syjonizmem politycznym, na co już w przeszłości zwrócił zasadnie uwagę znany historyk i publicysta syjonistyczny - Jakub Zineman, iż „pomiędzy duchowo-mesjanistycznym syjonizmem Mojżesza Hessa a późniejszym syjonizmem Leona Pinskera i Teodora Herzla istnieje zasadnicza różnica. Podczas gdy Pinsker i Herzl doszli do syjonizmu powodowani nędzą życia politycznego i ekonomicznego Żydów, to Hess szuka w Palestynie zbawienia dla kultury i mesjanistycznego ducha żydostwa. Różnica ta w światopoglądzie syjońskim pogłębi się później i skrystalizuje w ostrym antagonizmie pomiędzy politycznym syjonizmem Herzla a duchowym Ahada Haama" (Zineman, 1935, s. 34-35).

\section{DZIAŁALNOŚĆ PUBLICYSTYCZNA I POLITYCZNA ALFREDA NOSSIGA}

Budzący się ruch syjonistyczny na ziemiach polskich w ostatnim ćwierćwieczu XIX wieku chętniej sięgał już więc do koncepcji i propozycji syjonizmu politycznego L. Pinskera, a następnie T. Herzla, Nathana Birnbauma, Nahmana Syrkina i Maksa Nordau, aniżeli do twórczości ideowej M. Hessa. Sami też jego promotorzy podejmowali próby opracowania stanowiska doktrynalnego i ideowego nowego ruchu. Uwidoczniło się to szczególnie na terenie Galicji we Lwowie, Tarnowie i Krakowie. W stolicy zaboru austriackiego, w tym samym roku, kiedy powstało Stowarzyszenie „Syjon”, znany już wówczas, początkujący literat, publicysta i działacz społeczny, w przyszłości również polityk, artysta rzeźbiarz, muzyk i statystyk - Alfred Nossig (1864-1943) opublikował pierwszą w Polsce rozprawę poświęconą politycznemu syjonizmowi: Próba rozwiązania kwestii żydowskiej, będącą przedrukiem cyklu artykułów pomieszczonych w drugim półroczu poprzedniego roku w lwowskim miesięczniku o profilu demokratyczno-ludowym „Przegląd Społeczny”, redagowanym przez Bolesława Wysłoucha (Nossig, 1886). Choć był znacząca postacią w żydowskim i polskim życiu publicznym i kulturalno-naukowym, nie poświęcono mu poza biogramem w Polskim Słowniku Biograficznym poważniejszych opracowań i studiów (Piber, 1978). Wychował się on bowiem w rodzinie Ignacego Nossiga, sekretarza gminy żydowskiej we Lwowie, człowieka wykształconego i światłego, zwolennika asymilacji. Jego siostrą była Felicja, działaczka ruchu feministycznego, matka Adama Próchnika z nieformalnego związku z Ignacym Daszyńskim. Sam Alfred Nossig 
uzyskał gruntowne wykształcenie, gdyż studiował prawo, filozofię, ekonomię i medycynę na uniwersytetach we Lwowie, Zurychu i w Wiedniu, uwieńczone uzyskaniem doktoratu. Zanim rozpoczął studia ekonomiczne i socjologiczne w połowie lat osiemdziesiątych XIX wieku nad położeniem społeczności żydowskiej w Polsce i Europie, następnie przystąpił do sformułowania założeń idei syjonistycznej, rozwijał aktywną działalność w ruchu asymilatorskim, między innymi współpracując ze Stowarzyszeniem Przymierze Braci - Agudas Achim oraz jego organem prasowym - „Ojczyzna”, redagując go nawet w 1881 roku. W rozwijanej wówczas wczesnej twórczości literackiej poszukiwał inspiracji i wzorców w kanonie polskiej literatury pięknej. Jednakże pod wpływem budzącego się odrodzenia narodowego Żydów i kształtującego się ruchu syjonistycznego coraz więcej uwagi poświęcał kwestii żydowskiej. Jeszcze przed ogłoszeniem wspomnianego cyklu artykułów w lwowskim „Przeglądzie Społecznym” opublikował studium ekonomiczno-socjologiczne Uber die bevolkerung (Wien 1885). Zapoczątkował nim liczne opracowania dotyczące położenia socjalno-ekonomicznego ludności żydowskiej, jej terytorialnego rozmieszczenia oraz dziejów i kultury, uzasadniając rozwiązanie kwestii żydowskiej przede wszystkim poprzez odrodzenie państwa żydowskiego w Palestynie. Pragnął w ten sposób dowieść naukowych przesłanek idei syjonistycznej (Nossig: 1887a, 1894, 1903, 1904a, 1904b, 1920, 1921, 1922a, 1922b). W tym celu założył w Berlinie w 1902 roku Żydowski Instytut Statystyki i Demografii, w ramach którego inicjował opracowywanie odpowiednich materiałów statystyczno-demograficznych w postaci serii wydawniczej Judische statistik, stanowiących podstawę naukową projektu odbudowy państwa żydowskiego na terenie Palestyny. Stawiało go to wśród najlepszych znawców kwestii żydowskiej na przełomie XIX i XX wieku. Uczestniczył także od zjazdu założycielskiego w Bazylei (1897) w międzynarodowym ruchu syjonistycznym, pozostając jednak w ostrym konflikcie z przywódcą Światowego Kongresu Żydów - Teodorem Herzlem z powodów charakterologicznych i różnicy poglądów w kwestii sposobów i form kolonizacji żydowskiej w Palestynie i odbudowy państwa żydowskiego. Zapewne Herzl nie był skłonny uznać prekursorskiej roli Nossiga w opracowaniu idei syjonizmu politycznego oraz że ktoś wyprzedził go o całą dekadę. Toteż w czasie obrad zjazdu bazylejskiego nie zaproponował stanowiska drugiego wiceprezesa Światowego Kongresu Żydów autorowi Próby rozwiązania kwestii żydowskiej, lecz mało znanemu, młodemu działaczowi syjonistycznemu z Tarnowa, adwokatowi Abrahamowi Salzowi, który zetknął się z nim zapewne w czasie swych studiów prawniczych na uniwersytecie wiedeńskim. Pomimo że Nossig od 1889 roku 
mieszkał w Wiedniu, a następnie w Berlinie, utrzymywał jednak żywe kontakty ze środowiskiem polskim, między innymi z Ignacym Paderewskim w sprawach literacko-muzycznych i politycznych oraz z opiniotwórczymi ośrodkami krajowej prasy polskiej - „Słowem Polskim”, „Kurierem Polskim”, „Kurierem Warszawskim”, „Prawdą”, zamieszczając na ich łamach teksty literackie i korespondencje zagraniczne. Po zakończeniu wojny często przebywał w Warszawie, podtrzymując szerokie kontakty towarzyskie, także w świecie kultury i polityki. Na początku lat dwudziestych starał się pozyskać czołowych polskich polityków do swych planów utworzenia federacji państw europejskich, a także zbliżenia francusko-niemieckiego oraz porozumienia niemiecko-polskiego, w wyniku którego Polska miała odstąpić Niemcom odzyskany po wojnie fragment Pomorza za wybudowanie jej portu morskiego. W późniejszych latach kontynuował wysiłki i działania na rzecz bezpieczeństwa i pokoju, propagując ideę zbliżenia między narodami i wyznaniami religijnymi, oraz współpracy ogólnoeuropejskiej (Marszałek, 2996; Łastawski, 2003). Po dojściu Adolfa Hitlera do władzy opuścił Niemcy i osiadł w Szwajcarii, po czym w 1934 roku zamieszkał w Pradze. Znaczną też część czasu spędzał w swym dawnym rodzinnym Lwowie, zabiegając o pozyskanie od władz i społeczeństwa polskiego funduszy na wykonanie monumentalnej rzeźby Góra Święta (Nossig, 1934), usytuowanej na górze Karmel i mającej symbolizować współpracę narodu żydowskiego z innymi narodami w dziele odbudowy państwa żydowskiego i urzeczywistnienia pokoju w świecie. W następnym roku po wybuchu drugiej wojny światowej przybył do Warszawy i po utworzeniu getta usiłował zainteresować niemieckie władze okupacyjne planem emigracji Żydów z Generalnej Guberni. Na polecenie władz niemieckich został członkiem Judenratu i zamieszkał w getcie przy ul. Muranowskiej 42. Donosił im na swych rodaków. W styczniu 1943 roku przedłożył warszawskiemu gestapo sześciostronicowe opracowanie o żydowskim ruchu oporu, włącznie z podaniem informacji i planów o ściśle zakonspirowanych kryjówkach podziemia żydowskiego. Wówczas kierownictwo Żydowskiej Organizacji Bojowej, rozpoznawszy jego faktyczną rolę w getcie, wydało na niego wyrok śmierci, który w kilka tygodni później wykonano (Mulak, 1990). Potwierdziło się bowiem po latach, iż był on zaufaną osobą gestapo jako stary współpracownik wywiadu niemieckiego jeszcze sprzed I wojny światowej, którą to działalność agenturalną kontynuował nawet $\mathrm{z}$ hitlerowskim gestapo po 1933 roku.

Druga, owa haniebna i zdradziecka strona aktywności, bezsprzecznie wybitnego intelektualisty, stała się zapewne bezpośrednią przyczyną przemilczenia i skazania go na zapomnienie. Aczkolwiek jeszcze przed ujawnieniem faktycznej 
roli w niemieckim systemie represyjnym i niemieckiej polityce, jego nazwisko pojawiało się niezwykle rzadko, wręcz incydentalnie, w literaturze traktującej o syjonizmie. Za głównego bowiem twórcę ruchu i ideologii syjonistycznej uznawano niezmiennie Teodora Herzla, nie szczędząc mu hołdów i hagiograficznych ocen typu: „,arystokrata duchowy”, „wielki wizjoner”, świetny pisarz”, „głęboki intelektualista”, ,wielki nasz wódz i nauczyciel” itp. (Zineman, 1946). Tymczasem Nossig wywarł również znaczący wpływ na życie intelektualne i ideowe swojej epoki, szczególnie na przełomie dwóch poprzednich wieków. Jego działalność ideowa i organizatorska w międzynarodowym ruchu syjonistycznym nie była wszak jedyną i najważniejszą, gdyż zaznaczył swój udział wielu innych obszarach i dziedzinach życia społecznego: literaturze, sztuce muzycznej i plastycznej, publicystyce, polityce, myśli społecznej itp. Jednakże najtrwalszym i najbardziej interesującym śladem jego aktywności pozostaje niewątpliwie podjęta próba zdefiniowania ruchu syjonistycznego i idei syjonistycznej i jej realizacji. Swymi przemyśleniami intelektualnymi i ideowymi zawartymi w przywołanej już rozprawie: Próba rozwiązania kwestii żydowskiej (1887) wyprzedził on o całą dekadę wystąpienie uznanego za twórcę - ojca syjonizmu - Teodora Herzla ze słynną „biblią syjonizmu” - Der Judenstaat (1896), o popularności której przesądziła również forma wypowiedzi: wręcz publicystyczna i łatwa w percepcji, odwołująca się do emocji czytelnika, oraz oczywiście odpowiednio promowana w wielu krajach, gdyż szybko przełożona na liczne języki świata. Natomiast lwowski autor nadał swojemu tekstowi bardziej naukowy charakter, wprowadzając liczne analizy statystyczne i odwołując się do literatury fachowej, by w sposób naukowy uzasadnić główny cel budzącego się żydowskiego ruchu narodowego - była nim odbudowa państwa na terytorium Palestyny. Poza wydaniem niemieckim, i oczywiście polskim, jego rozprawa nie doczekała się szerszej percepcji w środowisku żydowskim.

\section{PRÓBA ROZWIĄZANIA KWESTII ŻYDOWSKIEJ}

Wcześniej - jak już wzmiankowałem - pełny tekst rozprawy opublikował A. Nossig w lwowskim „Przeglądzie Społecznym”. Zawarty w niej bogaty materiał statystyczny i socjologiczny zaczerpnął również z przywołanego już tutaj swojego źródłowego opracowania: Materialien zur Statistik der judischen Stammes, którego fragmenty publikował wcześniej na łamach warszawskiego czasopisma „Izraelita” (1886), i opracowania Statystyka Żydów w Europie (1886). Składa się 
ona z dwóch części: pierwsza, obszerniejsza - Zarys demografii szczepu żydowskiego zawiera charakterystykę stosunków ludnościowych, ekonomicznych, społeczno-politycznych, kulturalno-umysłowych i moralno-etycznych, oraz druga - Projekt polityki w kwestii żydowskiej przedstawia cele tworzącego się ruchu syjonistycznego i program ich realizacji. Za punkt wyjścia koncepcji syjonistycznej przyjął on założenie o konfliktogennym charakterze współżycia ludności żydowskiej w każdym nowym miejscu osiedlenia, gdyż - jak pisał - „od dwóch niemal tysięcy lat widzą ludy obok siebie odłamy rozproszonego szczepu żydowskiego. Ze wspólnego tego pożycia wyradzały się w prawie bez przerwy stosunki nader opłakane zarówno dla Żydów, jak i narodów ich otaczających. W czasach najnowszych stosunki te w wielu miejscach doszły do nieznośnego stopnia napięcia; a nie bez powodu wypowiadamy przypuszczenie, że ukształtują się one w przyszłości raczej gorzej, aniżeli korzystniej. Czas położyć kres owym ścieraniom i zatargom, objętym nazwą kwestii żydowskiej” (Nossig, 1887b, s. 1). Winą za trudne położenie swych rodaków obarczał ich sąsiadów. Jednocześnie podnosił przewagę życia żydowskiego w każdym jego przejawie nad ludnością miejscową. Przede wszystkim zwracał uwagę na wysoką, przewyższająca nawet trzykrotnie, w stosunku do ludności nieżydowskiej, dynamikę procesów demograficznych Żydów. Tłumaczył ją zwiększoną płodnością kobiet żydowskich, zawieraniem małżeństw w stosunkowo wczesnym wieku, prowadzeniem bardziej racjonalnego trybu życia, przebywaniem w otoczeniu nieprzyjaznym, wymuszającym życie w odosobnieniu, wydłużeniem życia i spadkiem śmiertelności dzieci w wyniku poprawy zdrowotności i higieny, ograniczeniem współżycia małżeńskiego i seksualnego do rodzimej grupy etnicznej itp. Szczególnie w tej ostatniej przesłance upatrywał on zachowanie w diasporze czystości rasowej Żydów, dziedziczących cechy antropologiczne dawnych starożytnych Hebrajczyków. Istniejące zaś pomiędzy nimi różnice, np. między odłamem żydowskiej społeczności sefardyjskiej a aszkenazyjskiej, wynikać miały z terytorialnego miejsce osiedlenia, co miało być zjawiskiem właściwym dla każdego narodu zamieszkującego różne obszary świata. Wykazują oni - jak żaden inny naród - duże zdolności przystosowawcze do nowych warunków przyrodniczych i klimatycznych, co zapewnia im wysoki dobrostan życia. Utrwaliły się one jeszcze jako pewne cechy „biotyczne” pod wpływem nieustannej walki o przetrwanie biologiczne i fizyczne w niesprzyjającym otoczeniu przyrodniczym i społecznym. A to znowu wskutek prześladowań i konieczności zapewnienia bytu wzmocniło więzi etniczne i solidarność wspólnotową, silnie motywowane czynnikami religijno-narodowymi i rozbudzanymi celową i świadomą polityką przywódców żydow- 
skich. Współcześnie wśród społeczności żydowskiej występują dwie orientacje: pierwsza, dominująca, o charakterze religijno-narodowym, wedle której należy oczekiwać na spełnienie się wyznania wiary judaistycznej i zapowiedzi proroków o przyjściu Mesjasza i odrodzeniu Izraela, oraz druga - kwestionująca religijno-narodowe przesłanie i opowiadająca się za asymilacją w kraju osiedlenia jako najpewniejszej drogi osiągnięcia przez Żydów postępu i awansu cywilizacyjnego. Ich postawy i zachowania, w sumie ponad sześciomilionowej rzeszy ludzi, są zróżnicowane w zależności od sytuacji i położenia w danym kraju osiedlenia: od pełnej izolacji, wrogości i prześladowań, podbudowanych nienawiścią rasową i religijną w krajach zachodnioazjatyckich i północnoafrykańskich, poprzez częściowe ograniczenie praw i swobód ekonomicznych i społeczno-politycznych oraz silnym niekiedy antysemityzmie w Europie Środkowo-Wschodniej, aż po pełną emancypację i widoczną asymilację w społeczeństwach zachodniej Europy i w Ameryce Północnej. To wszystko powoduje, że współcześnie kwestia żydowska jest zjawiskiem złożonym, którego rozwiązania w sposób harmonijny i skuteczny nie zapewnia dotychczasowa polityka; wręcz przeciwnie - wzmaga na podłożu rasowym, religijnym, ekonomiczno-społecznym i kulturowym nienawiść i prześladowania w różnych formach i postaciach, w zależności od stopnia poziomu cywilizacyjnego danego państwa. Jej rozwiązanie wymaga wnioskował A. Nossig - zastosowania nowych środków i sposobów. Tym bardziej, że dotyczy ona społeczności, będącej nie tylko wspólnotą religijną, lecz również narodową. O jej narodowej istocie i charakterze decyduje bowiem między innymi pochodzenie ze jednej siedziby terytorialnej, wspólna przeszłość, jednolite cechy biologiczno-fizyczne, zachowanie „czystości plemiennej”, posługiwanie się literackimi językami: hebrajskim i jidysz, zachowanie silnych więzi etnicznych opartych na „więzach krwi”, wzmocnionych jeszcze więzią terytorialną dużych ich skupisk (miasta) w krajach osiedlenia, dysponowanie odpowiednią organizacją polityczną w postaci samorządu gminnego i licznych stowarzyszeń, prowadzenie różnorodnego i bogatego życia umysłowego o charakterze literackim, artystycznym i edukacyjnym, wyznawanie religii monoteistycznej, silnie przenikniętej pierwiastkami narodowymi i mesjanistycznymi i stanowiącej podstawę ładu narodowego, a także przestrzeganie wspólnych wartości moralnych i zasad obyczajowych oraz zachowanie silnego poczucia narodowego przez większość Żydów - w ośmiu dziesiątych ich ogółu itp. Wszystko to sprawia, iż współcześnie Żydzi stanowią „prawidłową i zupełną narodowość”. Dlatego dziś już nie wystarcza im polityka emancypacyjna i asymilacyjna, gdyż nie odpowiada osiągniętemu etapowi rozwoju narodowego, 
społecznego, kulturowego i cywilizacyjnego. Oczekiwania ich są już dużo większe i zasadnicze. Tym bardziej, iż procesowi emancypacyjnemu zagrażają narastające ze strony ludności nieżydowskiej poważne sprzeczności i konflikty na tle ekonomicznym, politycznym i społecznym, które w nieodległej przyszłości mogą doprowadzić do tragicznych w skutkach wystąpień antyżydowskich na skalę masową. W tej sytuacji większość społeczności żydowskiej, by zachować wspólnotę narodową - przewidywał autor - opowie się za polityką odbudowy państwa izraelskiego na terytorium Palestyny. Natomiast mniejszość żydowska pozostanie w dotychczasowych krajach osiedlenia i całkowicie się zasymiluje z narodami nieżydowskimi. O masowej emigracji, właściwie reemigracji do historycznej ojczyzny Izraela przesądzi również religijność Żydów, podtrzymujących wiarę w przyjście Mesjasza, dzięki któremu zakończy się okres diaspory i nastąpi odrodzenie państwa izraelskiego. Może ono nastąpić jedynie na terytorium Palestyny, której idea przenika różne odłamy judaizmu na samym jej obszarze oraz bliskich jej terytoriów, między innymi w krajach zachodnioazjatyckich, północnoafrykańskich i wschodnioeuropejskich, gdzie występują liczne skupiska ludności żydowskiej, której położenie i warunki życia są bardzo trudne. W tej sytuacji jedynym koniecznym rozwiązaniem jest założenie państwa żydowskiego w Palestynie, kraju będącym jak dowodził A. Nossig - „ojczyzną Żydów niegdyś przez nich opuszczoną, narodową tradycją uświetnioną, której odzyskania spodziewają się oni na mocy religijnych dogmatów i przepowiedni; Palestyna i tylko Palestyna wchodzi w program konserwatywnej większości Żydów, jako też w programy oświeconych »przyjaciół Syjonu «. Ogół zmuszony do emigracji, skoro chodzić będzie nie o przedłużenie wygnania, ale o narodową restaurację - żadną miarą nie da się nakłonić do obrania innego kraju. Przez osiedlenie się w Palestynie cały przyszły ruch przybierze charakter reemigracji: Palestyna jest krajem mało zaludnionym, nie zajętym przez żaden ucywilizowany organizm narodowy i państwowy, a naturalne jego źródła dochodu leżą prawie ugorem; jest to jeden $\mathrm{z}$ niewielu, jeśli nie jedyny kraj, w którym przy odpowiedniej pracy wzrost źródeł dochodu mógłby dotrzymać kroku wzrastania ludności żydowskiej; jako kraj wschodni w ogóle, w szczególności zaś jako pierwotna siedziba Żydów, jest on ze względów klimatycznych dla Żydów najodpowiedniejszym" (Nossig, 1887b, s. 71).

Nadawał przeto Nossig idei syjonizmu uniwersalny charakter wyzwoleńczy, ponieważ spełnienie jej głównego celu, jakim miała być odbudowa państwa żydowskiego, zaspakajało potrzeby nie tylko ludności żydowskiej, lecz również jej sąsiadów w krajach osiedlenia. Są tym zainteresowani zarówno Żydzi, jak i ich 
sąsiedzi. Rozwiązanie bowiem kwestii żydowskiej ma z jednej strony uwolnić ludność nieżydowską od wszelkich negatywnych skutków współistnienia z ludnością żydowską, a tej zaś zapewnić pełną wolność i rozwój, pozwalając osiągnąć wyższy poziom cywilizacyjny i kulturalny. Warunkiem spełnienia tych celów jest przyjęcie koncepcji radykalnego i skutecznego rozwiązania kwestii żydowskiej, niemożliwego do zakwestionowania w przyszłości i urzeczywistnionego możliwie w najkrótszym czasie, by uniknąć narastających konfliktów Żydów $\mathrm{z}$ ich sąsiadami. Do tej pory proponowane rozwiązania nie były skuteczne, ponieważ miały często charakter doraźny i prowizoryczny, dotyczyły jedynie grupy ludności żydowskiej z danego kraju lub obszaru osiedlenia, nie uwzględniały natomiast czynnika historycznego i narodowego itp. Dlatego dotychczasowe różne propozycje i działania nie przynosiły oczekiwanych rezultatów, np. polityka asymilacji czy emancypacji Żydów poprzez upowszechnianie oświaty i wykształcenia, równouprawnienie i poprawę położenia ekonomicznego, reformę religijną i podnoszenie poziomu etycznego, względnie chrystianizację lub islamizację, a nawet całkowite pozbawienie dotychczasowych praw i swobód. Wyobrażalne jest również - dodawał Nossig - zorganizowanie mniejszości żydowskiej w dotychczasowych krajach osiedlenia na zasadzie odpowiedniej autonomii albo przesiedlenie jej do kilku wybranych krajów. Ale żaden z tych sposobów nie doprowadzi do rozwiązania kwestii żydowskiej, ponieważ nie jest to możliwe w przypadku tak nabrzmiałych i skomplikowanych, o wysokim stopniu konfliktowości, wzajemnych stosunkach ludności żydowskiej z ludnością nieżydowską. W tej sytuacji jedynym realnym i skutecznym środkiem jej rozwiązania pozostaje planowa i dobrowolna emigracja (właściwie reemigracja) Żydów do Palestyny i odbudowa państwa izraelskiego. Powrót do historycznej siedziby jest najodpowiedniejszym rozwiązaniem, gdyż dla zdecydowanej większości Żydów o orientacji konserwatywnej oznacza spełnienie się mesjanizmu religijnego. Tym bardziej, iż pozwoli szybko zwrócić poniesione nakłady kapitałowe na kolonizację i ożywczo wpłynie na sąsiedni narody orientalne, zbliżając je do kultury i cywilizacji zachodniej. Aby ów projekt osadnictwa i odrodzenia państwa żydowskiego się powiódł, należy poprzez odpowiednią akcję uświadamiającą pozyskać diasporę żydowską oraz poparcie ludności nieżydowskiej, w tym przede wszystkim ich ugrupowań narodowych, a także przywódców mocarstw, współdecydujących o odrodzeniu Izraela. Po osiągnięciu tego celu należy przystąpić do opracowania planu założenia państwa żydowskiego, włącznie z określeniem w przyszłej konstytucji jego ustroju, zabezpieczenia pozycji 
międzynarodowej, rozwoju wewnętrznego i reformy judaizmu itp. Wszystkie te przygotowania organizacyjne powinny przejąć żydowskie stowarzyszenia kolonizacyjne $\mathrm{z}$ każdego kraju osiedlenia, połączone w skali ogólnoświatowej w silną, scentralizowaną organizację, wspieraną przez kapitał żydowski i powszechne świadczenia przez wszystkich Żydów. Trzeba bowiem pozyskać środki finansowe na wykupienie terytorium Palestyny oraz sfinansowanie kosztów utworzenia armii izraelskiej w celu ochrony reemigrantów i tworzonych władz izraelskich, zanim jeszcze powstanie państwo żydowskie, które zapewniłoby bezpieczeństwo i pokój nowemu społeczeństwu i państwu. Tym bardziej że odzyskanie Palestyny możliwe będzie zarówno poprzez akcję odpłatnej kolonizacji i działania dyplomatyczne, jak również akcję wojskowo-militarną. Jedynie zastosowanie wielu środków pozwoli definitywnie rozwiązać kwestię żydowską. Aby to osiągnąć, „wy zaś, członkowie samodzielnych szczęśliwych narodów, pośród których żyje naród żydowski - apelował w konkluzji swych rozważań Alfred Nossig - poznajcie w nim na prawdę przyjaciela i brata, nie w tym znaczeniu, jakie głosi zgubny frazes, i traktujcie go w tym duchu. Dopomóżcie mu do jedności i samodzielności, jaką się cieszyć winien każdy naród; dopomóżcie mu do tego, przede wszystkim ze względu na własne wasze dobro, które w przeciwnym razie będzie zagrożeniem i w rozwoju wstrzymaniem. Jeśli zaś zarazem i pomyślność żydowskiego narodu będzie przez to ugruntowaną i zabezpieczoną, któż z ludzi sprawiedliwych i światłych nie życzyłby mu tego? Żądacie rozwoju i szczęścia ludzkości; przyznajcież więc wszystkim narodom prawo rozwijania się i dążenia do bytu szczęśliwego" (Nossig, 1887b, s. 89).

\section{PROGRAM BAZYLEJSKI - JEGO MODYFIKACJE I KONTYNUACJE}

Jednakże nie prekursorskie idee syjonistyczne Alfreda Nossiga stały się założeniami nowego ogólnoświatowego ruchu żydowskiego - ruchu syjonistycznego, formalnie powołanego na pierwszym kongresie syjonistycznym w Bazylei w dziesięć lat po wystąpieniu lwowskiego ideologa. I nie jemu też przypadła rola twórcy tego ruchu i jego ideologii, lecz Teodorowi Herzlowi, którego wspomniana rozprawa Der Judenstaat, ogłoszona w lutym 1896 roku, uznana została za biblię syjonizmu i zyskała wielką popularność zwłaszcza wśród Żydów środkowo-wschodnioeuropejskich, stając się wykładnią doktryny syjonistycznej (Herzl, 2006; Surzyn, 2014). Swym podtytułem: Próba rozwiązania kwestii żydowskiej przypominała tytuł rozprawy Alfreda Nossiga. Wspólne było dla 
nich postawienie zasadniczego celu tworzącego się ruchu syjonistycznego rozwiązania kwestii żydowskiej poprzez odbudowę państwa izraelskiego na terytorium Palestyny i uzasadnienie procesu przekształcenia żydowskiej wspólnoty etniczno-religijnej w nowoczesny naród zorganizowany wzorem narodów europejskich w państwo narodowe. Miało ono bowiem powstać przy poparciu czynników międzynarodowych w Palestynie, czyli „ziemi bez ludu”, tzn. bez Żydów - „ludu bez ziemi” - poprzez osiedlenie na jej terytorium. Miało być państwem nowoczesnym o nowym ustroju społecznym ze „słoneczną perspektywą wolności, szczęścia i honoru" w formie republikańsko-demokratycznej, zachowującym neutralność w stosunkach międzynarodowych, zabezpieczających interesy narodowe mniejszości etnicznych i urzeczywistniającym zasady sprawiedliwości społecznej. Miało być wzorem demokratyzmu, nowoczesności i humanitaryzmu dla innych narodów i organizacji państwowych.

Der Judenstaat stał się podstawą przyjętego w Bazylei programu budowy państwa izraelskiego w Palestynie. Jego autor stanął też na czele tworzącego się międzynarodowego ruchu syjonistycznego. Co prawda ów program bazylejski, ogólny i lapidarny (Hurewitz, 1956; Vital, 1975) nie odbiegał znowu zasadniczo od koncepcji i postulatów zawartych w rozprawie Alfreda Nossiga Próba rozwiqzania kwestii żydowskiej, lecz kierunek jego realizacji nadawał już kto inny: myśliciel i polityk wiedeński. On bowiem doprowadził do zwołania wspomnianego kongresu bazylejskiego i konsolidacji międzynarodowego ruchu syjonistycznego, stając na czele powołanej Światowej Organizacji Syjonistycznej jako ośrodka skupiającego wszystkie organizacje syjonistyczne na świecie i koordynującego ich działania na rzecz utworzenia państwa izraelskiego na terytorium Palestyny. Pod jego przywództwem bujnie rozwijał się ruch syjonistyczny, nie stając się jednak nigdy ruchem większościowym Żydów. Tym bardziej, iż spełnienie jego celów nie było zadaniem łatwym, pomimo dużego wsparcia finansowego, dyplomatycznego i moralnego ze strony zamożnych i wpływowych grup żydowskich z zachodniej Europy i Ameryki Północnej, ponieważ przeciwna mu była znaczna część opinii światowej i polityki międzynarodowej. Sprzeciwiała się mu również duża część samej ludności żydowskiej, zwłaszcza ultraortodoksyjnych Żydów, uznających za przedwczesne budowanie państwa izraelskiego, gdyż nie pojawił się jeszcze Mesjasz, a tylko on może wprowadzić „wybrany naród” do Ziemi Obiecanej. Zwalczał go również stosunkowo silny w Europie Środkowo-Wschodniej żydowski socjalistyczny ruch robotniczy (Bund), opowiadający się za uregulowaniem kwestii żydowskiej w krajach osiedlenia na zasadzie autonomii narodowo-kulturalnej, z wykorzystaniem języka żydowskiego - jidysz. 
W dodatku, od pierwszych chwil ustalenia doktryny syjonistycznej pojawiło się w niej wiele nurtów i orientacji wzajemnie się zwalczających, między innymi syjonizm kulturowy, syjonizm polityczny, syjonizm socjalistyczny, syjonizm religijny, syjonizm rewizjonistyczny itp.

Najpoważniejsze jednak trudności sprawiały władze tureckie, które pomimo nieustających zabiegów samego Herzla i jego przyjaciół nie wyrażały zgody na legalne osadnictwo Żydów w swej dawnej ojczyźnie. Wówczas rozpoczęto intensywne poszukiwania innych terytoriów osadnictwa żydowskiego: od krajów Dalekiego Wschodu - Jamajki i Wietnamu poprzez kraje Azji Mniejszej, Europy Środkowo-Wschodniej, Afryki (Madagaskar lub Uganda) i Ameryki Południowej (Argentyna). Ostatecznie jesienią 1902 roku wybrano Ugandę, którą to kolonię afrykańską zamierzały udostępnić osadnictwu żydowskiemu władze brytyjskie. Początkowo propozycję tę popierał Teodor Herzl, napotykając jednak na silny sprzeciw znacznej części ruchu syjonistycznego, o mało co nie doprowadziło to do rozłamu w tym ruchu. Stała się ona bowiem przedmiotem ostrego sporu na szóstym kongresie syjonistycznym w Bazylei, w sierpniu 1903 roku. Wśród jej zdecydowanych oponentów występował Alfred Nossig. W przemówieniu kongresowym i w specjalnie opracowanej rozprawie w języku niemieckim, wydanej następnie w lutym 1904 roku we Lwowie w języku polskim, wspomnianej już Kolonizacji żydowskiej w Palestynie, bronił idei utworzenia państwa izraelskiego w Palestynie. Przyczyny dotychczasowych niepowodzeń kolonizacyjnych postrzegał nie tylko w niechętnej polityce tureckiej, lecz także $\mathrm{w}$ nieodpowiednim przygotowaniu organizacyjnym i ekonomicznym akcji osiedleńczej. Nie stwarzają one jednak - jak sądził - przesłanek do rezygnacji z odbudowy państwa żydowskiego w Palestynie, gdyż wkrótce w obliczu narastającego kryzysu bałkańskiego i rozkładu państwa osmańskiego władze tureckie mogą w ramach reorientacji swej polityki zagranicznej udostępnić na zasadach autonomicznych Palestynę osadnictwu żydowskiemu. Należy przeto skoncentrować się na kolonizacji Palestyny i krajów sąsiednich, prowadzonej w sposób planowy i systematyczny, wspartej działaniami dyplomatycznymi i w razie potrzeby akcją zbrojną, a nie poszukiwać nowych, egzotycznych obszarów dla przyszłego państwa izraelskiego, np. w Ugandzie. Próba kolonizacji brytyjskiej posiadłości może się bowiem okazać ze względów ekonomicznych, klimatycznych, komunikacyjnych, politycznych i zdrowotnych przedsięwzięciem ryzykownym i niewykonalnym. Dlatego jedynym naturalnym programem syjonistycznym pozostaje projekt kolonizacji Palestyny i krajów sąsiednich, za realizacją którego przemawiają argumenty historyczne, religijne i ekonomiczne. Powinna ona 
przybrać charakter nie tylko rolniczy, lecz również miejski i przemysłowy.W tej sytuacji - wnioskował autor - pozostając w zgodzie ze stanowiskiem pierwszego kongresu bazylejskiego, należy przystąpić do realizacji „nowego programu kolonizacyjnego” opartego na następujących zasadach: „dzieło kolonizacji Palestyny przez Żydów należy bez przerwy i energicznie kontynuować; należy je przygotować przez nabywanie odpowiednich terytoriów; kolonizacja nie powinna ograniczyć się do tureckiej Palestyny, lecz sięgać i w terytoria krajów ościennych; kolonizacja ma mieć prócz rolniczego, także charakter miejski i przemysłowy; kolonizację mają wyprzedzić odpowiednie badania, a prowadzić je należy na podstawie jednolitego planu; kolonizacja ma być zupełnie legalną, równolegle z nią mają iść starania o coraz wyższe prawne gwarancje” (Nossig, 1904b, s.43)

W celu pozyskania środowisk żydowskich dla swojego programu kolonizacyjnego Nossig zorganizował liczne zgromadzenia i wiece w Niemczech, na których przyjmowano odpowiednie rezolucje. Założył wtedy stowarzyszenie „Orient Colonising Company Ltd”, mające koordynować akcję kolonizacyjną, a w 1908 roku - Allgemeine Judische Kolonisationsprogrammm. Prowadził także odpowiednie rozmowy z kapitałem żydowskim i negocjacje z władzami tureckimi. Wysuwał się wówczas na przywódcę międzynarodowego ruchu syjonistycznego, co ułatwiło mu zaprzestanie przez T. Herzla działalności wskutek choroby i śmierci w lipcu 1904 roku. Przez znaczną jednak część żydowskiej opinii syjonistycznej traktowany był jako uzurpator, zmierzający do rozbicia ruchu syjonistycznego. Ostatecznie kres jego planom położył wybuch wielkiej wojny. Dopiero po jej zakończeniu i ożywieniu w dyplomacji europejskiej i amerykańskiej sprawy osadnictwa żydowskiego w Palestynie powrócił do swych przedwojennych projektów syjonistycznych. Przede wszystkim w uzasadnieniu ich zasadności i racjonalności politycznej i ekonomicznej odwoływał się do argumentów natury religijnej, narodowej i mesjanistycznej. Przekonywał, iż w istocie są one spełnieniem i naturalną kontynuacją planów odbudowy w Palestynie państwa żydowskiego, głoszonych w przeszłości przez twórców i komentatorów judaizmu. W ten sposób program syjonistyczny uzyskał sankcję i legitymizację religijno-mesjanistyczną, rozwijaną przez proroków wyznania wiary ludu izraelskiego. Dlatego - wnioskował - należy w konstruowaniu planu odzyskania i urządzenia Palestyny sięgać do nauki proroków, gdyż tam są najwłaściwsze wskazówki, jak postępować, by osiągnąć upragniony cel. Właśnie w nauce mojżeszowej, będącej w istocie wyznaniem wiary socjalizmu światowego, odnaleźć można założenia wizji odrodzenia państwa izraelskiego - nowego ładu społecznego o charakterze socjalistycznym, tworzonego na nowo od podstaw i mogącego 
stanowić dla innych narodów wzór przebudowy społecznej. Pierwszorzędnymi przeto przesłaniami ideowymi dla współczesnego programu syjonistycznego pozostaje poszukiwanie pośredniego pomiędzy kapitalizmem a socjalizmem modelu społeczno-ekonomicznego i kulturowego, ewolucyjność i wieloetapowość przemian społecznych oraz oparcie tych przemian na gruncie demokracji. Przyszłe więc państwo izraelskie będzie państwem socjalizmu demokratycznego, realizowanym stopniowo, w którym początkowo będą współistnieć różne formy własności i sposoby gospodarowania oraz różnorodność postaw i zachowań społecznych, religijnych, narodowych itp. Odbudowane więc państwo żydowskie w Palestynie, nad którym jako terytorium neutralnym sprawować będzie nadzór Liga Narodów, może stać się wzorowym miejscem trwałego pokojowego i demokratycznego współżycia społeczności trzech religii: judaizmu, chrześcijaństwa i islamu. W ten sposób - konkludował Alfred Nossig - spełni się „idea palestyńska proroków, jedno z najdonioślejszych i najcudowniejszych wydarzeń historii świata. Od tysięcy lat pracuje pokolenie po pokoleniu nad tymże samym dziełem. I niewzruszona pozostaje nasza wiara: mimo wszystkich wewnętrznych i zewnętrznych przeszkód, odbudujemy na tej przez proroków wskazanej drodze Palestynę jako miejsce najwyższego podniesienia dla nas i dla ludzkości” (Nossig, 1920, 30; zob. też inne jego prace: 1921; 1922a; 1922b; 1901-1902).

\section{KONKLUZJE}

Autor rozprawy Próba rozwiązania kwestii żydowskiej opracował w sumie zwarty program syjonistyczny, który jednak nie stał się programem zorganizowanego międzynarodowego ruchu syjonistycznego. Uzupełniał i wzbogacał go o nowe rozwiązania i propozycje, wynikające z rozwoju sytuacji międzynarodowej i zmiany położenia diaspory żydowskiej. Osią organizująca ów program pozostał niezmiennie projekt odbudowy państwa żydowskiego na historycznym terytorium - Palestynie. Po doświadczeniach wielkiej wojny i rewolucji skonkretyzował wizję tego państwa jako organizacji nowego typu, gdyż państwa nowoczesnego o ustroju sprawiedliwości społecznej w formie republikańsko-demokratycznej, zachowującego neutralność w stosunkach międzynarodowych oraz zabezpieczającego prawa i wolności obywatelskie w wielokulturowym społeczeństwie. Miało ono być wzorem demokratyzmu, nowoczesności i humanitaryzmu dla innych narodów i organizacji państwowych. W ten sposób jego promotor wpisywał się w dzieło tworzenia i rozwoju wielkiego ruchu wyzwoleńczego narodu żydow- 
skiego, zwłaszcza jego niższych warstw społecznych - syjonizmu, wywierając wpływ na postawy i zachowania jego wyznawców i zwolenników. I roli tej nie może umniejszyć bądź przesłonić agenturalna działalność na rzecz nazizmu niemieckiego - sprawcy ludobójstwa na niespotykaną dotąd skalę w dziejach ludzkości.

\section{BIBLIOGRAFIA:}

(1934). Święta Góra. Pomnik symboliczny Alfreda Nossiga. Kraków.

(1946). 50-lecie „Państwa Żydowskiego” Teodora Herzla. Łódź: Centralny Komitet Zjednoczenia Syjonistów Demokratów w Polsce „Ichud”.

Feldman, W. (1893). Asymilatorzy, syjoniści i Polacy. Z powodu przełomu w stosunkach żydowskich $w$ Galicji. Kraków: Księgarnia S. Barańskiego.

Gołczewski, F. (1981). Polnisch-judische Beziehungen 1881-1922. Eine Studie zur Geschichte des Antisemitismus in Osteuropa. Wiesbaden: Franz Steiner.

Hertzberg, A. (1986). The Zionist Idea. A Historical Analysis Und Reader. New York: The Jewish Publication Society Philadelphia and Jerusalem..

Herzl, T. (2006). Państwo żydowskie. Próba nowoczesnego rozwiązania kwestii żydowskiej. Przekł. J. Surzyn. Kraków: Wydawnictwo „Austeria”.

Hess, M. (1899). Rom Und Jerusalem. Die Letzte Nationalitatenfrage. Leipzig.

Hurewitz, J.C. (1956). Diplomacy in the Near and Middle East. A Documentary Record. Princeton: D. Van Nostrand Company.

Łastawski, K. (2003). Od idei do integracji europejskiej. Warszawa: Wydawnictwo Wyższej Szkoły Pedagogicznej TWP.

Marszałek, A. (1996). Z historii europejskiej idei integracji międzynarodowej. Łódź: Wydawnictwo Uniwersytetu Łódzkiego.

Mulak, J. (1990). Polska lewica socjalistyczna 1939-1944. Warszawa: Wydawnictwo „Książka i Wiedza”.

Nossig, A. (1886). Próba rozwiązania kwestii żydowskiej. Przegląd Społeczny, 8-12, $130-419$.

Nossig, A. (1887a). Materialen zur Statistik des judischen Stammes. Wien: Interterritorialer Verlagts „Renaissance”.

Nossig, A. (1887b). Próba rozwiązania kwestii żydowskiej. Lwów.

Nossig, A. (1894) Einfuhrung in das Dtudium der Sozialen Higiene. Geschichtlieche Entwicklung und Bedeutung der offentlichen Gesundheitspfleger. Stuttgart: Deutsche Verlagts-Anstatt in Stuttgart.

Nossig, A. (1901-1902). Revision des Sozialismus. Das System des Sozialismu, cz. 1-2. Berlin.

Nossig, A. (1903). Die Bilans des Zionismus. Berlin: Interterritorialer Verlagts „Renaissance".

Nossig, A. (1904a). Das Judische Kolonisationsprogramm. Berlin: Interterritorialer Verlagts „Renaissance”. 
Nossig, A. (1904b). Kolonizacja żydowska w Palestynie. Lwów: Żydowska Spółka Wydawnicza „Kadimach”.

Nossig, A. (1920). Odbudowa Palestyny. Łódź: Wydawnictwo TEL-AWiW.

Nossig, A. (1921a). Bolszewizm a żydostwo. Warszawa: Instytut Wydawniczy „Renaissance".

Nossig, A. (1921b). Polen und Juden. Die polnisch-judische Berstandigung zur Regelung der Judenfrage in Polen. Wien: Interterritorialer Verlagts „Renaissance”.

Nossig, A. (1922a). Integrales Judentum. Vom integralen Program der judischen Bewegung. Der Wiederaufbau Palestinum. Sozialismus und Mosaismus. Wien: Interterritorialer Verlagts „Renaissance”.

Nossig, A. (1922b). Zionismus und Judenheit. Krisis und Losung. Berlin: Interterritorialer Verlagts „Renaissance”.

Piber, A. (1978). Alfred Nossig, Polski Słownik Biograficzny, 23, 236-240.

Pinsker, L. (1900). Samowyzwolenie. Apel do Żydów. Warszawa.

Ringel, M. (1910). Społeczeństwo polskie wobec syjonizmu. Lwów: Drukarnia Udziałowa we Lwowie.

Shimoni, G. (1995). The Zionist Ideology. Hannower: University Press of New England, for Brandeis University Press.

Sroka, Ł., Bruti, B. (red). (2017). Polish-Israel Cooperation Experience: from Zionism to Israel. Kraków-Kefar Sawa: Wydawnictwo Naukowe Uniwersytetu Pedagogicznego im. KEN w Krakowie.

Surzyn, J. (2014). Antysemityzm. Emancypacja. Syjonizm. Narodziny ideologii syjonistycznej. Katowice. Wydawnictwo Uniwersytetu Śląskiego.

Vital, D. (1975). The Origins of Zionism. Oxford: Oxford University Press.

Wróbel, P. (1991). Zarys dziejów Żydów na ziemiach polskich w latach 1880-1918. Warszawa: Wydawnictwo Uniwersytetu Warszawskiego.

Zineman, J. (1935). Historia syjonizmu, t. 1. (okres przed-herzlowski). Warszawa: Wydawnictwo „Nasze Życie”. 